\title{
KONSEP DAN EKSISTENSI BIMBINGAN DAN KONSELING SEJALAN DENGAN SISTEM PENDIDIKAN ABAD 21
}

Tiara Alwafa Nissa Huang

Fakultas Matematika dan Ilmu Pengetahuan Alam, Universitas Negeri Padang

Email : tiarahuang99@gmail.com

\begin{abstract}
Manusia adalah mahluk filosofis, artinya manusia mepunyai pengetahuan dan berpikir, manusia juga memiliki sifat yang unik, berbeda dengan mahluk lain dalam pekembanganya. Seiring dengan perkembangan IPTEK sistem pendidikan selalu mengalami pembaruan demi menyesuaikan diri. Di abad 21 pelaksanaan pendidikan menjadi tak bisa lepas dari teknologi. Eksistensi dan Kedudukan Bimbingan dan Konseling di Sekolah selalu sama, yaitu berguna untuk mengembangkan potensi pada diri individu sesuai dengan kemampuannya agar bisa menyesuaikan diri dengan lingkungan, baik lingkungan sekolah, lingkungan keluarga, dan lingkungan masyarakat. Layanan bimbingan dan konseling di abad 21 di upgrade demi membantu siswa dalam menghadapi permasalahan yang lebih kompleks. Artikel ini membahas konsep bimbingan dan konseling serta eksistensinya di dalam sistem pendidikan abad 21.
\end{abstract}

Kata kunci : bimbingan dan konseling, abad 21, eksistensi bimbingan dan konseling, dan kompetensi.

\section{PENDAHULUAN}

Bimbingan dan Konseling merupakan pekerjaan pelayanan yang professional yang menguraikan pemahaman, penanganan dan penyikapan tentang keadaan seseorang yang meliputi unsur kognisi, afeksi, dan psikomotori. Pekerjaan ini sangat penting sekali dalam dunia pendidikan, agar tercipta keserasian atau keharmonisan antara guru dengan siswa. Hal ini sesuai dengan Undang-Undang No. 20 Tahun 2003 tentang Sistem Pendidikan Nasional Pasal 1 Ayat 1 dan 6 : Pendidikan adalah usaha sadar dan terencana untuk mewujudkan suasana belajar dan proses pembelajaran agar peserta didik secara aktif mengembangkan potensi dirinya untuk memiliki 
kekuatan spiritual keagamaan, pengendalian diri, kepribadian, kecerdasan, akhlak mulia, serta keterampilan yang diperlukan dirinya, masyarakat, bangsa dan negara.

Perkembangan dunia abad 21 ditandai dengan pemanfaatan teknologi informasi dan komunikasi dalam segala segi kehidupan, termasuk dalam proses pembelajaran. Dunia kerja menuntut perubahan kompetensi. Kemampuan berpikir kritis, memecahkan masalah, dan berkolaborasi menjadi kompetensi penting dalam memasuki kehidupan abad 21. Menyikapi hal ini, Sekolah dituntut mampu menyiapkan siswa memasuki abad 21.

Eksistensi dan Kedudukan Bimbingan dan Konseling di Sekolah selalu sama, yaitu berguna untuk mengembangkan potensi pada diri individu sesuai dengan kemampuannya agar bisa menyesuaikan diri dengan lingkungan, baik lingkungan sekolah, lingkungan keluarga, dan lingkungan masyarakat. Hal inilah yang merupakan tujuan utama pelayanan bimbingan dan konseling di sekolah, terutama bagi siswa-siswi sebagai individu yang diberi bantuan.

\section{TINJAUAN PUSTAKA}

\section{A. Konsep Bimbingan dan Konseling}

Istilah bimbingan merupakan terjemahan dari kata guidance (Bahasa Inggris). Secara etimologis bimbingan berasal dari kata "guide" yang artinya mengarahkan (direct), menunjukkan (pilot), mengatur (manage), menyetir (steer). Sesuai dengan istilahnya, maka secara umum bimbingan dapat diartikan sebagai suatu bantuan atau tuntunan. Namun, meskipun demikian tidak berarti semua bentuk bantuan atau tuntunan adalah bimbingan.

Dari beberapa pengertian bimbingan yang dikemukakan oleh banyak ahli itu, dapat dikemukakan bahwa bimbingan merupakan: (a) suatu proses yang berkesinambungan, (b) suatu proses membantu individu, (c) bantuan yang diberikan itu dimaksudkan agar individu yang bersangkutan dapat mengarahkan dan mengembangkan dirinya secara optimal sesuai dengan kemampuan/potensinya, dan (d) kegiatan yang bertujuan utama memberikan bantuan agar individu dapat memahami keadaan dirinya dan mampu menyesuaikan dengan lingkungannya.

Bimbingan merupakan bantuan kepada individu dalam menghadapi persoalan-persoalan yang dapat timbul dalam hidupnya. Bantuan semacam itu sangat tepat jika diberikan di sekolah, supaya setiap siswa lebih berkembang ke arah yang semaksimal mungkin. Dengan demikian bimbingan 
menjadi bidang layanan khusus dalam keseluruhan kegiatan pendidikan sekolah yang ditangani oleh tenaga-tenaga ahli dalam bidang tersebut.

Istilah konseling berasal dari bahasa Inggris "to counsel” yang secara etimologis berarti "to give advice" atau memberi saran dan nasihat. Konseling sebagai terjemahan dari "Counseling" merupakan bagian dari bimbingan, baik sebagai layanan maupun sebagai teknik.

Istilah konseling juga sering diartikan sebagai penyuluhan. Istilah penyuluhan dalam kegiatan bimbingan menurut para ahli kurang tepat. Menurut mereka yang lebih tepat adalah konseling, karena kegiatan konseling ini sifatnya lebih khusus, tidak sama dengan kegiatan-kegiatan penyuluhan lain seperti penyuluhan dalam bidang pertanian dan penyuluhan dalam keluarga berencana. Pelayanan konseling menuntut keahlian khusus, sehingga tidak semua orang yang dapat memberikan bimbingan mampu memberikan jenis layanan konseling ini.

Dari definisi bimbingan dan konseling yang sudah dijelaskan di atas secara terpisah dapat dikemukakan pengertian bimbingan dan konseling secara bersama-sama yaitu suatu kegiatan pemberian layanan bimbingan atau bantuan kepada individu maupun kelompok agar dapat mengenali dan memahami dirinya dan seluruh potensi yang ada pada dirinya sehingga mampu mengembangkannya seoptimal mungkin guna menghadapi dan menyesuaikan diri dengan lingkungan yang ditempatinya.

Dari pengertian bimbingan dan konseling di atas dapat diambil beberapa hal pokok, yaitu: (1) Bimbingan dan konseling merupakan pelayanan bantuan. (2) Pelayanan bimbingan dan konseling dilakukan melalui kegiatan secara perorangan dan kelompok. (3) Arah kegiatan bimbingan dan konseling ialah membantu peserta didik untuk melaksanakan kehidupan seharihari secara mandiri dan berkembang secara optimal. (4) Ada empat bidang bimbingan yaitu bimbingan pribadi, sosial, belajar, dan karir. (5) Pelayanan bimbingan dan konseling dilaksanakan melalui jenis-jenis layanan tertentu, ditunjang sejumlah kegiatan pendukung. (6) Pelayanan bimbingan dan konseling harus didasarkan pada norma-norma yang berlaku.

B. Eksistensi dan Kedudukan Bimbingan dan Konseling di sekolah 
Rotherdam \& Willingham (2009) mencatat bahwa kesuksesan seorang siswa tergantung pada kecakapan abad 21, sehingga siswa harus belajar untuk memilikinya. Partnership for $21^{\text {st }}$ Century Skills mengidentifikasi kecakapan abad 21 meliputi : berpikir kritis, pemecahan masalah, komunikasi dan kolaborasi. Berpikir kritis berarti siswa mampu mensikapi ilmu dan pengetahuan dengan kritis, mampu memanfaatkan untuk kemanusiaan. Trampil memecahkan masalah berarti mampu mengatasi permasalahan yang dihadapinya dalam proses kegiatan belajar sebagai wahana berlatih menghadapi permasalahan yang lebih besar dalam kehidupannya. Ketrampilan komunikasi merujuk pada kemampuan mengidentifikasi, mengakses, memanfaatkan dan memgoptimalkan perangkat dan teknik komunikasi untuk menerima dan menyampaikan informasi kepada pihak lain. Terampil kolaborasi berarti mampu menjalin kerjasama dengan pihak lain untuk meningkatkan sinergi. Sedang menurut National Education Association untuk mencapai sukses dan mampu bersaing di masyarakat global, siswa harus ahli dan memiliki kecakapan sebagai komunikator, kreator, pemikir kritis, dan kolaborator.

Pada dasarnya sistem pendidikan tidak berubah banyak, namun kompetensi yang dituntut semakin tinggi dan semakin sulit tingkatannya. Paradigma pembelajaran abad 21 menekankan kepada kemampuan siswa untuk berpikir kritis, mampu menghubungkan ilmu dengan dunia nyata, menguasai teknologi informasi komunikasi, dan berkolaborasi. Pencapaian ketrampilan tersebut dapat dicapai dengan penerapan metode pembelajaran yang sesuai dari sisi penguasaan materi dan ketrampilan.

Semakin banyak isu-isu tentang betapa besar nya tantangan abad 21 mampu menarik perhatian sebagian besar orang dan menimbulkan kecemasan dan rasa khawatir, sehingga perhatian mereka tepusat penuh pada isu itu. Jarang sekali isu kepribadian siswa diungkit, apalagi peran guru Bimbingan dan Konseling atau konselor sekolah dalam pembentukan pribadi siswa.

Bimbingan Konseling seolah menjadi topik yang tidak penting untuk dibicarakan. Padahal, kalau merujuk ke negara yang pendidikannya maju, seperti Amerika Serikat, Singapura, bahkan Malaysia, peran guru BK sangat diperhatikan. Beberapa minggu yang lalu seorang teman di Malaysia bercerita betapa berkembanganya ilmu BK di negeri itu. Lalu, kenapa di Indonesia isu tentang BK menjadi isu nomor 2, kalaupun diangkat, bukan menjadi isu nasional tetapi daerah. Gerakan yang terlihat malah dari daerah, bahkan dari sekolah-sekolah. Padahal peran guru Bk sangat di butuhkan dalam menyiapka siswa yang siap menghadapi tantangan abad 21. 
Eksistensi dan Kedudukan Bimbingan dan Konseling di Sekolah selalu sama, yaitu berguna untuk mengembangkan potensi pada diri individu sesuai dengan kemampuannya agar bisa menyesuaikan diri dengan lingkungan, baik lingkungan sekolah, lingkungan keluarga, dan lingkungan masyarakat. Hal inilah yang merupakan tujuan utama pelayanan bimbingan dan konseling di sekolah, terutama bagi siswa-siswi sebagai individu yang diberi bantuan.

Eksistensi dan Kedudukan Bimbingan dan Konseling di Sekolah berarti menentukan pula keberhasilan dari tujuan pendidikan. Sedangkan berhasil tidaknya tujuan tersebut bergantung pada pelaksanaan program pelayanan bimbingan dan konseling itu sendiri. Kerjasama yang baik dari semua pihak seperti kepala sekolah, para guru pengajar sekaligus guru pembimbing, orang tua juga masyarakat akan sangat menentukan. Dari uraian di atas jelaslah yang hendak dicapai oleh program bimbingan dan konseling adalah tingkat perkembangan yang optimal bagi setiap individu sesuai dengan kemampuan, agar dapat mengenal diri dan menyesuaikan diri dengan lingkungan, baik lingkungan keluarga, sekolah maupun masyarakat.

Fakta-fakta yang tampak adalah bahwa meski peradaban berkembang pesat tidak semua orang mampu mengimbanginya. Di abad 21 ini karakter siswa masih sama pada dasarnya. Masih banyak siswa yang bahkan tidak mengenal diri mereka sendir, tidak bisa menentukan tujuan mereka sendiri, tidak tau bakat dan kadang kala bingung terhadap minat mereka sendiri. Hal ini menjadi semakin sulit karena mereka hidup di abad 21, di massa dimana setiap individu mampu berpikr jauh kedepan, mampu merencanakan tujuan dan mampu mencapainya. Masa dimana mereka yang masih tidak yakin akan menjadi begitu tertinggal.

Layanan bimbingan dan konseling merupakan salah satu bentuk fasilitasi terhadap siswa untuk mencapai tugas-tugas perkembangan. Salah satunya adalah mengenal kemampuan, bakat, minat, serta arah kecenderungan karier dan apresiasi seni yang merupakan aspek kematangan wawasan dan kematangan karier dalam Standar Kompetensi Kemandirian Siswa (SKKPD). Keberhasilan karier seorang individu berawal dari perencanaan karier yang tepat dan sesuai dengan potensi karier yang dimiliki. Salah satu hal yang mempengaruhi perencanaan karier siswa ialah pengenalan akan potensi diri dan potensi karier yang tepat. Untuk dapat mengenali hal tersebut dibutuhkan peran dari guru BK saat ini. Generasi Z di abad 21 membutuhkan peran seorang guru BK yang dengan layanan-layanan BK yang disesuaikan dengan keadaan abd 21. Abad 21 dengan generasi $\mathrm{Z}$ nya dihadapkan pada berbagai tantangan untuk mencapai karier yang optimal. Tantangan 
tersebut dapat ditanggulangi dengan bimbingan karier yang tepat. Terdapat faktor pendukung dan penghambat perencanaan karier yang dilakukan siswa. Oleh karena itu, peran guru BK abad 21 untuk meningkatkan kemampuan perencanaan karier siswa sangat diperlukan.

\section{KESIMPULAN}

pengertian bimbingan dan konseling secara bersama-sama yaitu suatu kegiatan pemberian layanan bimbingan atau bantuan kepada individu maupun kelompok agar dapat mengenali dan memahami dirinya dan seluruh potensi yang ada pada dirinya sehingga mampu mengembangkannya seoptimal mungkin guna menghadapi dan menyesuaikan diri dengan lingkungan yang ditempatinya.

Eksistensi dan Kedudukan Bimbingan dan Konseling di Sekolah selalu sama, yaitu berguna untuk mengembangkan potensi pada diri individu sesuai dengan kemampuannya agar bisa menyesuaikan diri dengan lingkungan, baik lingkungan sekolah, lingkungan keluarga, dan lingkungan masyarakat. Hal inilah yang merupakan tujuan utama pelayanan bimbingan dan konseling di sekolah, terutama bagi siswa-siswi sebagai individu yang diberi bantuan. 


\section{DAFTAR PUSTAKA}

Association, N. E. Preparing 21st Century Students for a Global Society : An Educator's Guide to the "Four Cs".

Bimo Walgito, Bimbingan dan Konseling di Sekolah, Yogyakarta: Andi, 2004.

Center, P. P. (2010). 21st Century Skills for Students and Teachers. Honolulu:: Kamehameha Schools, Research \& Evaluation Division.

Dewa Ketut Sukardi. 2009. Pengantar Pelaksanaan Program Bimbingan dan Konseling di Sekolah. Jakarta: PT Rineka Cipta. 